\title{
DIFFERENCES IN PERIPHERAL VASCULAR RESPONSE OF A FIBROMYALGIA PATIENT IN A PHYSICAL FATIGUE SITUATION: A CASE CONTROL REPORT
}

\author{
Vicente Javier Clemente-Suárez ${ }^{5}$, Jose Alberto Parraca ${ }^{2}$ *, Vanda Lapao Silva ${ }^{13}$, Nuno \\ Batalha $^{12}$, Ana Rodrigues Costa ${ }^{4}$, Pablo Tomas-Carus ${ }^{12}$
}

\begin{abstract}
CLEMENTE-SUÁREZ, V. J; PARRACA, J. A.; SILVA, V. L.; BATALHA, N.; COSTA, A. R.; TOMAS-CARUS, P. Differences in peripheral vascular response of a fibromyalgia patient in a physical fatigue situation: a case control report.. Perspectivas Online: Biológicas \&Saúde, v.11, n. 40, p. $1-10,2021$.

The aim of the present case control report was to analyze peripheral vascular response of fibromyalgia patient in an intense physical exercise fatigue situation. We analyzed a female fibromyalgia patient, 55 years, $65 \mathrm{~kg}, 156 \mathrm{~cm}, 26.7 \mathrm{Kg} / \mathrm{m} 2$, with 3 year from the fibromyalgia diagnosis and 10 year of fibromyalgia symptomatology: and a control healthy female participant, 57 years, $73 \mathrm{~kg}, 163 \mathrm{~cm}, 27.5 \mathrm{Kg} / \mathrm{m} 2$. The peripheral vascular response by thermography was collected in 3 different moments, basal, post fatigue protocol (20

repetition of knee extension and flexion of dominant leg at $180^{\circ} \cdot \mathrm{s}-1$ ), and after $6 \mathrm{~min}$ of finishing the fatigue protocol. We found how fibromyalgia patient presented a higher basal heart rate, lower skin hand temperature in basal conditions, similar in an intense exercise fatigue protocol, and lower in the recovery of the protocol than a control participant, and a higher basal skin temperature of thigh muscles in basal condition, higher in the fatigue protocol and lower in the recovery after the fatigue protocol than a control participant.
\end{abstract}

Keywords: Fibromyalgia; Microcirculation; Peripheral nervous system; Thermography; Fatigue; Exercise.

\footnotetext{
${ }^{1}$ Department of Sports and Health, School of Health and Human Development, University of Évora, Largo dos Colegiais, 7000 Évora, Portugal

${ }^{2}$ Comprehensive Health Research Centre (CHRC), Universidade de Évora, Évora, Portugal

${ }^{3}$ Family Health Unit - Lusitania, street do Ferragial do Poço Novo, S/N, 7000-727 - Évora, Potugal

${ }^{4}$ Institute of Earth Sciences (ICT) and Department of Chemistry, School of Sciences and Technology, University of Évora,

Rua Romão Ramalho, 59, 7000-671, Évora, Portugal

${ }^{5}$ University Europea of Madrid. Faculty of Sports Science. Spain

${ }^{6}$ Research Group on Culture, Education and Society. University of the Coast. Barranquilla. Colombia * Email: jparraca@uevora.pt

Receipt: 18/10/2021

Accepted for publication: 04/11/2021.

Date of Publicação 21/12/2021 .
}

Persp. Online: biol \& saúde, Campos dos Goytacazes, 40 (11) 1-10, 2021

ojs3.perspectivasonline.com.br 


\section{DIFERENÇAS NA RESPOSTA VASCULAR PERIFÉRICA DE UM PACIENTE COM FIBROMIALGIA EM UMA SITUAÇÃO DE FADIGA FÍSICA: UM RELATÓRIO DE CONTROLE DE CASO}

Vicente Javier Clemente-Suárez ${ }^{56}$, Jose Alberto Parraca ${ }^{2}$, Vanda Lapao Silva ${ }^{13}$, Nuno Batalha $^{12}$, Ana Rodrigues Costa ${ }^{4}$, Pablo Tomas-Carus ${ }^{12}$

\section{RESUMO}

CLEMENTE-SUÁREZ, V. J; PARRACA, J. A.; SILVA, V. L.; BATALHA, N.; COSTA, A. R.; TOMAS-CARUS, P Diferenças na resposta vascular periférica de um paciente com fibromialgia em uma situação de fadiga física: um relatório de controle de caso. Perspectivas Online: Biológicas \&Saúde, v.11, n. 40, p. 1 - 10, 2021.

O objetivo do presente estudo foi analisar a resposta vascular periférica de uma paciente com fibromialgia em situação de fadiga como resposta ao exercício físico intenso. Analisámos uma paciente com fibromialgia, 55 anos, $65 \mathrm{~kg}, 156 \mathrm{~cm}, 26,7$ $\mathrm{Kg} / \mathrm{m} 2$, com 3,5 anos do diagnóstico de fibromialgia e 10 anos de sintomatologia, e uma participante saudável controlo, 57 anos, $73 \mathrm{~kg}, 163 \mathrm{~cm}, 27,5 \mathrm{Kg} / \mathrm{m} 2$. A resposta vascular periférica por termografia foi coletada em 3 momentos distintos, basal, logo após a aplicação do protocolo de fadiga (20 repetições de extensão do joelho e flexão da perna dominante a $\left.180^{\circ} \cdot \mathrm{s}-1\right)$, e após 6 min do término do protocolo de fadiga. Verificámos que a paciente com fibromialgia apresentou maior frequência cardíaca basal, menor temperatura cutânea das mãos em condições basais, temperatura semelhante no protocolo de fadiga proposto, e menor na recuperação comparativamente com a participante controlo, e maior temperatura basal da pele dos músculos da coxa na condição basal, maior no protocolo de fadiga e menor na recuperação do que a participante controlo.

Palavras-chave: Fibromialgia; Microcirculação; Sistema nervoso periférico; Termografia; Fadiga; Exercício.

\footnotetext{
${ }^{1}$ Departamento de Desporto e Saúde, Escola de Saúde e Desenvolvimento Humano, Universidade de Évora, Largo dos Colegiais, 7000 Évora, Portugal

${ }^{2}$ Comprehensive Health Research Centre (CHRC), Universidade de Évora, Évora, Portugal

${ }^{3}$ Family Health Unit - Lusitania, Rua do Ferragial do Poço Novo, S/N, 7000-727 - Évora, Potugal

${ }^{4}$ Institute of Earth Sciences (ICT) and Department of Chemistry, School of Sciences and Technology, University of Évora, Rua Romão Ramalho, 59, 7000-671, Évora, Portugal

${ }^{5}$ Universidad Europea de Madrid. Faculty of Sports Science. Spain

${ }^{6}$ Grupo de Investigación en Cultura, Educación y Sociedad. Universidad de la Costa. Barranquilla. Colombia * Correspondence: iparraca@uevora.pt

Data de recebimento: 18/10/2021. 


\section{INTRODUCTION}

Fibromyalgia (FM) is a chronic disease which is mainly characterized by widespread musculoskeletal pain. This is accompanied by several social, mental and the physical health symptoms, being the most common fatigue, stiffness, sleep disturbance, and cognitive impairments (WOLFE; CLAUW; FITZCHARLES; GOLDENBERG et al., 2010). It was also associated with specific diseases such as rheumatic pathologies, psychiatric or neurological disorders, infections, diabetes, and a large prevalence of psychological disorders as anxiety, posttraumatic stress, somatization, dysthymia, panic disorders, and depression (BELLATO; MARINI; CASTOLDI; BARBASETTI et al., 2012; CLAUW; CROFFORD, 2003; GIESECKE; WILLIAMS; HARRIS; CUPPS et al., 2003; MEEUS; NIJS; HERMANS; GOUBERT et al., 2013). Several factors are involved in the etiology of this syndrome highlighting the dysfunction of the central and autonomic nervous systems, neurotransmitters, hormones, immune system, external stressors, psychiatric aspects, and others seem to be involved (BELLATO; MARINI; CASTOLDI; BARBASETTI et al., 2012). Central sensitization is considered the main mechanism involved, fact that increased the response to stimulation mediated by central nervous system signaling. Also, the exacerbated central sensitization produced by an impaired modulation of spinal cord responses to painful stimuli involving the descending inhibitory pain pathways are characteristic in FM (MEEUS; NIJS; HERMANS; GOUBERT et al., 2013)

Other authors found how FM patients presented blood microcirculation abnormalities and capillarity disorders due to modifications in the arteriovenous anastomoses innervation of the skin (ALBRECHT; HOU; ARGOFF; STOREY et al., 2013; CHOI; KIM, 2015). The arteriovenous anastomoses innervation is innervated by autonomous sympathetic fibers, founding large concentration in hands (ALBRECHT; HOU; ARGOFF; STOREY et al., 2013). Specifically, FM patients presents an increased arteriovenous anastomoses innervation with increased peptidergic sensory innervation over the sympathetic innervations, fact that could influence the vasodilation and sensory feedback mechanisms among capillaries and precapillary arterioles and finally flood circulation (AGUILAR-FERRANDIZ; CASASBARRAGAN; TAPIA-HARO; RUS et al., 2021). In this line, the thermogenesis of FM patients is also affected, presenting a higher body temperature due to the autonomous nervous system disorder that can affect blood microcirculation and sweating functions (ELMAS; YILDIZ; BILGIN; DEMIRCI et al., 2016). Actual authors described an increased hand temperature measured by thermography in FM patients (AGUILAR-FERRANDIZ; CASAS-BARRAGAN; TAPIA-HARO; RUS et al., 2021).

Exercise is one of the most effective treatments for fibromyalgia. Combat all symptoms of the disease, including pain, fatigue, and trouble sleeping. Physical activity can help maintain bone mass, improve balance, reduce stress, and increase strength (BIDONDE, 2021). In this line, there is known how aerobic exercise allow to reduce pain, fatigue, and depression and to improve health-related quality of life and physical fitness, since strength training was associated with large improvements in global well-being and physical function, and mixed exercise training (combination of aerobic and/or strength and/or flexibility exercises) was shown to produce large improvements in pain and physical function (BUSCH; WEBBER; BRACHANIEC; BIDONDE et al., 2011).

Persp. Online: biol \& saúde, Campos dos Goytacazes, 40 (11) 1-10, 2021

ojs3.perspectivasonline.com.br 
Finally, the psychophysiological and thermographic response of FM patients in physical activities, especially in fatigue conditions are still poor known. The difficult access of this population and the difficulty to perform fatigue protocols limited this knowledge. For this reason, we conducted the present case control research with the aim of to analyze peripheral vascular response of FM patient in an intense physical exercise fatigue situation

\section{MATERIALS AND METHODS}

\section{Experimental approach to the problem}

To reach the study aims we made evaluations of the psychophysiological and response of fibromyalgia and control participants before, after and 5' after complete a standardized fatigue protocol.

\section{Participants}

We analyzed a female FM patient, 55 years, $65 \mathrm{~kg}, 156 \mathrm{~cm}, 26.7 \mathrm{Kg} / \mathrm{m} 2$, with 3 years from the FM diagnosis and 10 year of FM symptomatology; and a control healthy female participant, 57 years, $73 \mathrm{~kg}, 163 \mathrm{~cm}, 27.5 \mathrm{Kg} / \mathrm{m} 2$. All the procedure was conducted following the Helsinki Declaration (as revised in Brazil, 2013) and approved by the University Ethical Committee (GD/44902/2019). The data were collected anonymously. Prior to participation, all participants were informed about the experimental procedures, indicating the right to withdraw from the study at any time and providing written informed consent.

\section{Procedure}

First participants signed the informed consent. Then cardiovascular basal response was evaluated with a chest band Kalenji (Bluetooth and ant+) and the program Golden Cheetah with the participants sited in a quiet room during $3 \mathrm{~min}$. Then, the peripheral vascular response by thermography was collected in 3 different moments, basal, post fatigue protocol and after 6 min of finishing the fatigue protocol. All thermal images were collected in compliance with the recommendations of the European Association of Thermology (RING; AMMER, 2012). The thermograms were obtained in a room with controlled and constant temperature of $20^{\circ} \mathrm{C}$ and $40 \%$ of humidity. Participants were in the room $20 \mathrm{~min}$ prior to the data collection for acclimatization purpose, and all the data collection were in the morning to control changes in circadian rhythms (LI; WANG, 2005). Following protocols of previous studies, the thermograms was first performed on the dorsal side and then on the palmar side of both hands, and then in the thigh of the participants. The analysis of the skin surface temperature was conducted locating the middle point of each dorsal and palmar fingertip, and through a circle at the centre of each dorsal and palmar hand (diameter $70 \times 70 \mathrm{~mm}$ ), then average of these 6 hand areas were made for dorsal and palmar of both hands (AGUILAR-FERRANDIZ; CASASBARRAGAN; TAPIA-HARO; RUS et al., 2021). For the skin surface temperature of thigh, we divided the thigh in two similar part from the knee joint to the hip and evaluated average of the central point of the upper thigh division and the central point of the lower thigh division (NILSSON; SUNDEN; ZETTERQUIST, 1979).

\section{Fatigue protocol}

Fatigue protocol was conducted in a Biodex System 3 isokinetic dynamometer (Biodex Corporation, Shirley, NY). The protocol started with a general warm up of 3 min cycling in a Monark 839E (Monark Exercise AB, Sweden) at 50- $60 \mathrm{rpm}$ with no resistance to avoid fatigue previous to the fatigue protocol. Then a specific warm up consisted in 3 repetition of knee

Persp. Online: biol \& saúde, Campos dos Goytacazes, 40 (11) 1-10, 2021 
extension and flexion of dominant leg was conducted with no resistance at free velocity. After that participants started the fatigue protocol performing 20 repetition of knee extension and flexion of dominant leg at $180^{\circ} \cdot \mathrm{s}-1$ (TOMAS-CARUS; ORTEGA-ALONSO; PIETILAINEN; SANTOS et al., 2016).

\section{RESULTS AND DISCUSSION}

The result of the present case control study showed how FM patients presented lower temperature in palmar and dorsal of both hands compared with the healthy control participant (Figure 1). The difference was large, showing in left dorsal values differenced up to $9{ }^{\circ} \mathrm{C}$. When both conducted the physical fatigue protocol the FM patients increased temperature, while control slightly decrease her temperature, but presenting both participants a temperature more similar than in basal conditions (Table 1). After the recovery phase the FM patient temperature return close to the basal values, decreasing temperature in all the areas analyzed. By contrary, control participant maintained temperature showing similar values in the three evaluation moments.

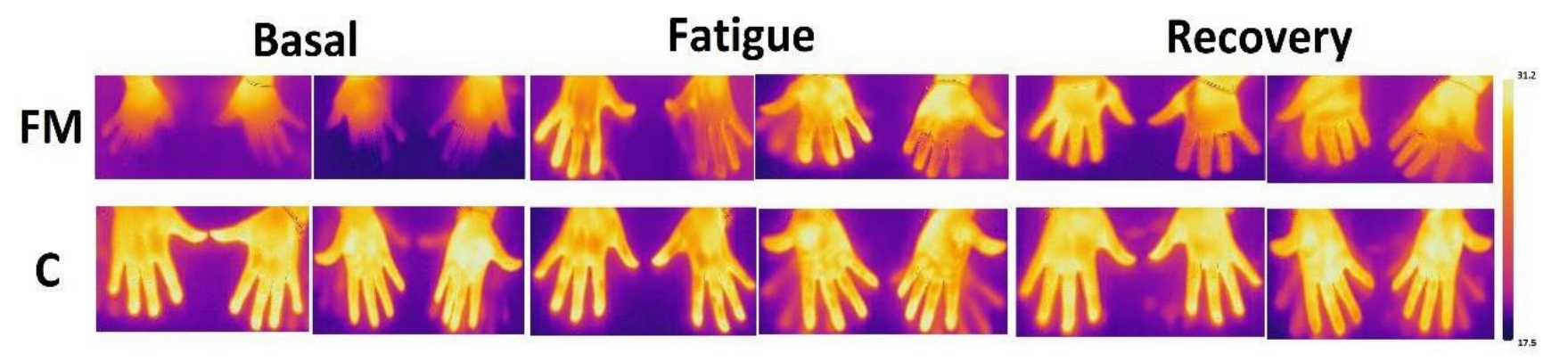

Figure 1. Temperature modification $\left(\mathrm{C}^{\mathrm{a}}\right)$ evaluated by thermography in fibromyalgia patient (FM) and control participant $(\mathrm{C})$ in basal, fatigue and recovery evaluation moments.

Table 1. Differences in hands temperature $\left({ }^{\circ} \mathrm{C}\right)$ in the 3 moments of analysis between Fibromyalgia and control participants.

\begin{tabular}{|c|c|c|c|c|c|c|c|c|c|c|c|c|}
\hline & \multicolumn{4}{|c|}{ Basal } & \multicolumn{4}{|c|}{ Fatigue } & \multicolumn{4}{|c|}{ Recovery } \\
\hline & \multicolumn{2}{|c|}{ Palmar } & \multicolumn{2}{|c|}{ Dorsal } & \multicolumn{2}{|c|}{ Palmar } & \multicolumn{2}{|c|}{ Dorsal } & \multicolumn{2}{|c|}{ Palmar } & \multicolumn{2}{|c|}{ Dorsal } \\
\hline & Right & Left & Right & Left & Right & Left & Right & Left & Right & Left & Right & Left \\
\hline Fibromyalgia & 21.0 & 21.3 & 20.5 & 20.8 & 30.0 & 25.7 & 23.8 & 18.7 & 24.3 & 22.6 & 21.2 & 19.2 \\
\hline Control & 30.7 & 30.9 & 29.5 & 29.9 & 28.9 & 29.8 & 28.0 & 29.1 & 29.0 & 30.0 & 29.8 & 30.8 \\
\hline
\end{tabular}

Previous authors found how FM patients presented an increased core body temperature related with the imbalance of the autonomic nervous system (ELMAS; YILDIZ; BILGIN; DEMIRCI et al., 2016). This finding was also found by other researcher using tympanic temperature (AGUILAR-FERRANDIZ; CASAS-BARRAGAN; TAPIA-HARO; RUS et al., 2021) and axillary temperature comparing FM with control participants, but in this last study no differences in tympanic temperature were found (BRUSSELMANS; NOGUEIRA; DE SCHAMPHELAERE; DEVULDER et al., 2015). This higher temperature of FM patients was explained by the vasodilation of arteriovenous anastomoses that is associated with a release of

Persp. Online: biol \& saúde, Campos dos Goytacazes, 40 (11) 1-10, 2021

ojs3.perspectivasonline.com.br 
substance $\mathrm{P}$ into the blood flow (CHARKOUDIAN, 2010). The substance P is normally released into the bloodstream after stressful condition (cold, heat or physical stress), but was also found increased in FM patients, fact that produce an increase of vasoactive and proinflammatory mediators that would explain the elevated core body temperature of this patients (THEOHARIDES; VALENT; AKIN, 2015). In this line, it was also found how the excessive peripheral vasodilation of the microvasculature of the hands and the autonomic nervous system disorder associated with abnormal innervation of the arteriovenous anastomoses in the glabrous skin of the hands of patients with FM produced an increased temperature in this area (AGUILAR-FERRANDIZ; CASAS-BARRAGAN; TAPIA-HARO; RUS et al., 2021; ALBRECHT; HOU; ARGOFF; STOREY et al., 2013).

The lower temperature of FM patient obtained in hand thermography in basal condition was opposite with previous literature (AGUILAR-FERRANDIZ; CASAS-BARRAGAN; TAPIA-HARO; RUS et al., 2021). Thermal monitoring studies comparing body areas bilaterally indicate that differences of up to 0.25 to $0.62{ }^{\circ} \mathrm{C}$ (FELDMAN; NICKOLOFF, 1984; MARINS; FERNANDEZ-CUEVAS; ARNAIZ-LASTRAS; FERNANDES et al., 2015) are considered acceptable, but higher values could indicate that the region with lower temperature could present a degenerative problem (HILDEBRANDT; RASCHNER; AMMER, 2010). In the present research we found differences between FM and control patient larger than the 0.62 ${ }^{\circ} \mathrm{C}$, fact revealing a completely different peripheral vascular status in the FM patient evaluated. It was identified how fibromyalgia patients present a higher sympathetic modulation (VILLAFAINA; COLLADO-MATEO; DOMINGUEZ-MUNOZ; GUSI et al., 2020), fact coinciding with the higher HR mean and maximum evaluated in the actual FM patient (Table 2). This higher sympathetic modulation could produce a higher vasoconstriction of peripheral vascular system that could explain the results obtained in the present case control research. In this line, the usual consumption of antidepression medication is associated with fluctuations in heart rate and blood pressure, as a result of autonomic nervous system dysfunctions, producing hypotension that could aggravate the dysfunctions in the peripheral vascularization (TULEN; BRUIJN; DE MAN; PEPPLINKHUIZEN et al., 1996).

Table 2. Heart rate of participants.

\begin{tabular}{lcc}
\hline & $\begin{array}{c}\text { Fibromyalgia } \\
\text { patient }\end{array}$ & $\begin{array}{c}\text { Control } \\
\text { participant }\end{array}$ \\
\cline { 2 - 2 } Heart rate mean $(\mathrm{bpm})$ & 84 & 78 \\
Heart rate maximum $(\mathrm{bpm})$ & 95 & 84 \\
\hline
\end{tabular}

Interestingly in the fatigue protocol conducted by both participant the skin hand thermography response was similar, presenting the FM patients an increase in peripheral vascular response, achieving a response more similar to the control participants. It seems that in eliciting muscular exercise the peripheral vascular response of FM patient appears to be more normal than in baseline conditions. In this line, when recovering after physical exercise, the peripheral vascular response returned to the original tend evaluated in basal conditions. These results open the door to analyze the effectiveness of intense exercise programs in this type of population to improve their peripheral vascular response. Regarding the thermography response of principal muscles involved in the fatigue protocol, we found how FM patient in this case presented a higher basal temperature in thigh than the control one, result consonant with the literature previously cited (AGUILAR-FERRANDIZ; CASAS-BARRAGAN; TAPIA-HARO; RUS et al., 2021; ALBRECHT; HOU; ARGOFF; STOREY et al., 2013). Interestingly we found how physical exercise produced a decrease of temperature in the thigh of FM patient, opposite response than control participants in where temperature increase (Table 3). The FM

Persp. Online: biol \& saúde, Campos dos Goytacazes, 40 (11) 1-10, 2021

ojs3.perspectivasonline.com.br 
patient thermographic response is opposite to the evaluated by previous authors in physical activities (SCHLADER; STANNARD; MUNDEL, 2010). The decrease in temperature in the active muscular area could preclude to maintain the physical effort on time, fact that could explain the limitation of FM patients to perform physical activities and the higher fatigue and pain perceptions of them. This novel response evaluated cold be related with the lower cold detection pain threshold of FM patients, fact that was related with an impaired sudomotor function in FM patients, but more studies are needed to clarify the nociception autonomic system function (PICKERING; ACHARD; CORRIGER; SICKOUT-ARONDO et al., 2020). Finally, the temperature after the fatigue protocol in the FM patient slightly increased, in opposition to the control participant, that maintain temperature after the recovery phase. Interestingly, the temperature values of the FM patient after recovery from the fatigue protocol were similar to the baseline values of the control participant. This fact could make us think about the usefulness of long-term protocols of high intensity training in FM patients for a regulation of their peripheral vascular response.

Table 3. Differences in thighs temperature $\left({ }^{\circ} \mathrm{C}\right)$ in the 3 moments of analysis between Fibromyalgia and control participants.

\begin{tabular}{lcccccc}
\hline & \multicolumn{2}{c}{ Basal } & \multicolumn{2}{c}{ Fatigue } & \multicolumn{2}{c}{ Recovery } \\
\cline { 2 - 7 } & Active & $\begin{array}{c}\text { Non } \\
\text { active }\end{array}$ & Active & $\begin{array}{c}\text { Non } \\
\text { active }\end{array}$ & Active & $\begin{array}{c}\text { Non } \\
\text { active }\end{array}$ \\
Fibromyalgia & 25.9 & 26.7 & 20.9 & 21.1 & 22.4 & 23.1 \\
Control & 23.6 & 24.2 & 27.5 & 28.4 & 27.7 & 28.4 \\
\hline
\end{tabular}

This was the first time that thermography response in FM patient was evaluated in intense exercise and the recovery after it. This information allows to better understand of physiology of FM allowing to open new research and treatment interventions.

This research presented several limitations, first one the fact that was a case control report, but the difficult to recruit FM patients to conduct intense fatigue exercise and technological and financial lack precluded a large study. Future research must explore the thermographic response in large samples of FM patients in different intensity exercise to allow a better physical activity prescription in this population

\section{CONCLUSIONS}

FM patient presented lower skin hand temperature in basal conditions than control participant, but similar after a physical fatigue protocol. Its seems how high intensity physical activity allow a better microcirculation of FM patients measured by thermography

\section{REFERENCES}

AGUILAR-FERRANDIZ, M. E.; CASAS-BARRAGAN, A.; TAPIA-HARO, R. M.; RUS, A. et al. Evaluation of sympathetic adrenergic branch of cutaneous neural control throughout thermography and its relationship to nitric oxide levels in patients with fibromyalgia. J Therm Biol, 95, p. 102813, Jan 2021. 
ALBRECHT, P. J.; HOU, Q.; ARGOFF, C. E.; STOREY, J. R. et al. Excessive peptidergic sensory innervation of cutaneous arteriole-venule shunts (AVS) in the palmar glabrous skin of fibromyalgia patients: implications for widespread deep tissue pain and fatigue. Pain Med, 14, n. 6, p. 895-915, Jun 2013.

BELlATO, E.; MARINI, E.; CASTOLDI, F.; BARBASETTI, N. et al. Fibromyalgia syndrome: etiology, pathogenesis, diagnosis, and treatment. Pain Res Treat, 2012, p. 426130, 2012.

BIDONDE, J., Boden, C., Foulds, H., \& Kim, S. Y. Physical Activity and Exercise Training for Adults with Fibromyalgia. Fibromyalgia Syndrome, p. 59-72, 2021.

BRUSSELMANS, G.; NOGUEIRA, H.; DE SCHAMPHELAERE, E.; DEVULDER, J. et al. Skin Temperature during Cold Pressor Test in Fibromyalgia: an Evaluation of the Autonomic Nervous System? Acta Anaesthesiol Belg, 66, n. 1, p. 19-27, 2015.

BUSCH, A. J.; WEBBER, S. C.; BRACHANIEC, M.; BIDONDE, J. et al. Exercise therapy for fibromyalgia. Curr Pain Headache Rep, 15, n. 5, p. 358-367, Oct 2011.

CHARKOUDIAN, N. Mechanisms and modifiers of reflex induced cutaneous vasodilation and vasoconstriction in humans. J Appl Physiol (1985), 109, n. 4, p. 1221-1228, Oct 2010.

CHOI, D. H.; KIM, H. S. Quantitative analysis of nailfold capillary morphology in patients with fibromyalgia. Korean Journal of Internal Medicine, 30, n. 4, p. 531-537, Jul 2015.

CLAUW, D. J.; CROFFORD, L. J. Chronic widespread pain and fibromyalgia: what we know, and what we need to know. Best Pract Res Clin Rheumatol, 17, n. 4, p. 685-701, Aug 2003.

ELMAS, O.; YILDIZ, S.; BILGIN, S.; DEMIRCI, S. et al. Physiological parameters as a tool in the diagnosis of fibromyalgia syndrome in females: A preliminary study. Life Sciences, 145, p. 51-56, Jan 152016.

FELDMAN, F.; NICKOLOFF, E. L. Normal thermographic standards for the cervical spine and upper extremities. Skeletal Radiol, 12, n. 4, p. 235-249, 1984.

GIESECKE, T.; WILLIAMS, D. A.; HARRIS, R. E.; CUPPS, T. R. et al. Subgrouping of fibromyalgia patients on the basis of pressure-pain thresholds and psychological factors. Arthritis Rheum, 48, n. 10, p. 2916-2922, Oct 2003.

HILDEBRANDT, C.; RASCHNER, C.; AMMER, K. An overview of recent application of medical infrared thermography in sports medicine in Austria. Sensors (Basel), 10, n. 5, p. 47004715, 2010.

Persp. Online: biol \& saúde, Campos dos Goytacazes, 40 (11) 1-10, 2021

ojs3.perspectivasonline.com.br 
LI, X. S.; WANG, D. H. Suppression of thermogenic capacity during reproduction in primiparous brandt's voles (Microtus brandtii). Journal of Thermal Biology, 30, n. 6, p. 431436, Aug 2005.

MARINS, J. C. B.; FERNANDEZ-CUEVAS, I.; ARNAIZ-LASTRAS, J.; FERNANDES, A. A. et al. Applications of Infrared Thermography in Sports a Review. Revista Internacional De Medicina Y Ciencias De La Actividad Fisica Y Del Deporte, 15, n. 60, p. 805-824, Dec 2015.

MEEUS, M.; NIJS, J.; HERMANS, L.; GOUBERT, D. et al. The role of mitochondrial dysfunctions due to oxidative and nitrosative stress in the chronic pain or chronic fatigue syndromes and fibromyalgia patients: peripheral and central mechanisms as therapeutic targets? Expert Opinion on Therapeutic Targets, 17, n. 9, p. 1081-1089, Sep 2013.

NILSSON, E.; SUNDEN, P.; ZETTERQUIST, S. Leg Temperature Profiles with a Simplified Thermographic Technique in the Diagnosis of Acute Venous Thromboses. Scandinavian Journal of Clinical \& Laboratory Investigation, 39, n. 2, p. 171-177, 1979.

PICKERING, G.; ACHARD, A.; CORRIGER, A.; SICKOUT-ARONDO, S. et al. Electrochemical Skin Conductance and Quantitative Sensory Testing on Fibromyalgia. Pain Pract, 20, n. 4, p. 348-356, Apr 2020.

RING, E. F.; AMMER, K. Infrared thermal imaging in medicine. Physiol Meas, 33, n. 3, p. R33-46, Mar 2012.

SCHLADER, Z. J.; STANNARD, S. R.; MUNDEL, T. Human thermoregulatory behavior during rest and exercise - a prospective review. Physiol Behav, 99, n. 3, p. 269-275, Mar 3 2010 .

THEOHARIDES, T. C.; VALENT, P.; AKIN, C. Mast Cells, Mastocytosis, and Related Disorders. N Engl J Med, 373, n. 19, p. 1885-1886, Nov 52015.

TOMAS-CARUS, P.; ORTEGA-ALONSO, A.; PIETILAINEN, K. H.; SANTOS, V. et al. A randomized controlled trial on the effects of combined aerobic-resistance exercise on muscle strength and fatigue, glycemic control and health-related quality of life of type 2 diabetes patients. Journal of Sports Medicine and Physical Fitness, 56, n. 5, p. 572-578, May 2016.

TULEN, J. H.; BRUIJN, J. A.; DE MAN, K. J.; PEPPLINKHUIZEN, L. et al. Cardiovascular variability in major depressive disorder and effects of imipramine or mirtazapine (Org 3770). J Clin Psychopharmacol, 16, n. 2, p. 135-145, Apr 1996.

Persp. Online: biol \& saúde, Campos dos Goytacazes, 40 (11) 1-10, 2021

ojs3.perspectivasonline.com.br 
VILLAFAINA, S.; COLLADO-MATEO, D.; DOMINGUEZ-MUNOZ, F. J.; GUSI, N. et al. Effects of exergames on heart rate variability of women with fibromyalgia: A randomized controlled trial. Sci Rep, 10, n. 1, p. 5168, Mar 202020.

WOLFE, F.; ClAUW, D. J.; FITZCHARLES, M. A.; GOLDENBERG, D. L. et al. The American College of Rheumatology preliminary diagnostic criteria for fibromyalgia and measurement of symptom severity. Arthritis Care Res (Hoboken), 62, n. 5, p. 600-610, May 2010. 